\title{
Does Information Risk Really Matter? An Analysis of the Determinants and Economic Consequences of Financial Reporting Quality
}

\author{
Daniel A. Cohen ${ }^{\mathrm{a}^{*}}$
}

${ }^{a}$ New York University

\begin{abstract}
Controlling for firm-specific characteristics determining financial reporting quality, this paper finds evidence of a negative association between firms' total risk and financial reporting quality. While the results imply that firms providing financial information of higher quality do not necessarily enjoy a lower cost of equity capital, a significant negative relation is documented between reporting quality and idiosyncratic risk. This suggests that the quality of accounting information is not an additional systematic priced risk factor as suggested in recent studies. The evidence reported demonstrates the importance of explicitly controlling for the determinants of financial reporting quality when investigating the associated economic consequences.
\end{abstract}

JEL Classification: D80, G12, G14, M41

Keywords: financial reporting quality, information risk, cost of capital, idiosyncratic risk

\section{Introduction}

This paper investigates the determinants and economic consequences of crosssectional variation concerning the quality of financial reporting. Whether disclosure policies and financial reporting affect a firm's cost of equity capital is one of the most interesting and important questions in the accounting and finance literature today. To date, there is a growing body of evidence that information quality and disclosure policy lower the equity cost of capital (e.g., Botosan, 1997; Easley and O'Hara, 2004; among others). However, this evidence is troubling for two reasons. First, classical asset pricing

* Correspondence address: 44 West $4^{\text {th }}$ Street, Suite 10-80, New York NY 10012. Tel: 212-998-0267. Fax: 212-995-4802. Email: dcohen@stern.nyu.edu. This paper is based on my dissertation completed at Northwestern University. I thank members of my dissertation committee: Robert Korajczyk, Robert Magee, and especially Thomas Lys (Chair) and Beverly Walther for their valuable comments, guidance and discussions. I thank workshop participants at the 2007 APJAE Symposium on Accounting in honor of A. Rashad Abdel-Khalik, especially Kevin Chen (discussant) and Rashad Abdel-Khalik. 
theory shows that diversifiable risks are not priced, and there is a paucity of compelling arguments for why information risk is diversifiable (e.g., Hughes et al., 2007; and Lambert et al., 2007). Secondly, most existing empirical studies take disclosure policy and financial reporting quality to be exogenous, although it is generally agreed that firms optimize their disclosure policy. Furthermore, the specific characteristics of firms that provide a certain quality of financial information may also affect the consequences of financial reporting. The purpose of this study is to extend prior literature by carefully identifying the determinants of firms' financial reporting quality and investigating whether there is any evidence that information risk affects the cost of equity capital once the firm-specific characteristics of this information risk are controlled for.

Economic theory suggests that, ceteris paribus, increasing the quality of financial information reduces information asymmetries and hence lowers the cost of capital (e.g., Easley and O'Hara, 2004). A firm can reduce information asymmetries between itself and market participants and between informed and uninformed investors by providing information that helps investors in their decision-making process. Using measures of accounting information quality, recent empirical work focuses on the association between earnings quality and the cost of capital (e.g., Francis et al., 2005) suggesting a negative association between the two. A significant shortcoming of numerous empirical studies is the failure to address the endogenous nature of disclosure and financial reporting quality. If researchers do not control for the determinants of disclosure and financial reporting policies, their inferences regarding the economic consequences of disclosure quality may be spurious (Fields et al., 2001). Firm-specific characteristics that determine the quality of financial information, for example, demands for capital, litigation costs, and incentive costs, make it difficult to interpret the association between information risk and capital markets valuation benefits documented in prior research. The research design used in this study specifically addresses these concerns by identifying the factors that determine the variation in financial reporting quality and the associated economic consequences.

In line with recent studies on the consequences of financial reporting quality (e.g., Core et al., 2007 and Francis et al., 2005), I measure reporting quality as the mapping between earnings and operating cash flows (Dechow and Dichev, 2002). I find evidence that higher investors' demands for firm-specific information are associated with higher quality of financial reporting. In addition, the results suggest that higher proprietary costs constrain the quality of financial information. My findings indicate that firms with high-quality financial reporting policies have lower idiosyncratic risk. However, I do not find evidence that firms providing high-quality financial information necessarily enjoy a lower cost of equity capital. The results documented imply that although information quality is associated with total firm risk, it is the idiosyncratic diversifiable component which drives this relation, rather than the systematic undiversifiable component.

I first replicate prior findings and provide evidence consistent with the results documented in these studies (Francis et al., 2005). I document that failure to control for firm characteristics that lead firms to have a certain quality of accounting information and enjoy a lower equity cost of capital may wrongly attribute the cost of capital benefit to information quality rather than to the underlying characteristics. In other words, the evidence suggests that the link found in previous research between a firm's quality of 
accounting information and its equity cost of capital results from a failure to consider the underlying factors determining the quality of financial reporting.

My analysis implies that the information risk associated with the quality of financial reporting does not necessarily constitute an additional systematic non-diversifiable risk factor, but rather is an idiosyncratic one. This finding suggests that capital markets participants are not likely to price the documented uncertainty as other risk factors, such as beta, size and book-to-market ratios. This result is consistent with recent theoretical work by Lambert et al. (2007) and Hughes et al. (2007).

The major contribution of my study is that it accounts for the underlying firmspecific characteristics related to the quality of their financial reporting when investigating the associated economic consequences. I show that the failure to do so affects the inferences made and conclusions drawn by previous studies. In addition, this study's findings have important implications for research on the consequences of firms' disclosure policies. The evidence I present suggests that the variation in financial reporting quality depends not only on the benefits firms expect to derive from disclosure, but also on other firm-specific attributes. Future work on determinants and consequences of financial reporting policies should thus consider not only the capital market benefits associated with financial reporting policies, but other firm-specific characteristics, such as product market characteristics, which constrain the quality of reported earnings.

The remainder of the paper is organized as follows. Section 2 provides a literature review and presents the theoretical background on the determinants and consequences associated with financial reporting policies. Section 3 describes the research design and addresses methodological issues. Section 4 presents the sample selection criteria and discusses the empirical results. Section 5 concludes the paper.

\section{Relation to Prior Research}

Theoretical research investigating the link between disclosure and a firm's cost of capital suggests a negative association between the two. In recent work, Easley and O'Hara (2004) demonstrate a link between information structure (private versus public information) and the cost of capital. Their model implies that firms can affect their cost of capital through the precision and quantity of the information they provide to investors. Building on the above theory, Francis et al. $(2004,2005)$ seek to provide evidence consistent with the pricing effects of information quality and claim that accrual quality is a systematic priced risk factor. The evidence documented in Francis et al. (2004, 2005) suggests that information seems to affect the cost of capital. These results are puzzling since the theoretical underpinning behind this finding relies on Easley and O'Hara's (2004) model which is still a prediction of how information asymmetry affects the cost of capital. Recently, numerous theoretical papers have questioned the Easley and O'Hara (2004) model. In particular, Lambert et al. (2007, pp. 396-397) argue that when the number of traders becomes large in the Easley and O'Hara (2004) model, the information effect is diversified away. If this claim is correct, the Easley and O'Hara (2004) model provides no support for the hypothesis that information risk or accounting quality is priced systematically by investors. In addition, Hughes et al. (2007) 
question the theoretical underpinnings of the specifications used in recent empirical studies and show that in large economies, idiosyncratic risk as well as the asymmetric information risk associated with idiosyncratic factors is fully diversifiable and should not affect the cost of capital in a systematic manner. Given these different theoretical models developed in Easley and O'Hara (2004), Hughes et al. (2007), and Lambert et al. (2007) an empirical question still remains as to whether information quality can be characterized as proxying for idiosyncratic components of assets payoffs which do not affect risk premiums or as a systematic undiversifiable factor which does affect the risk premium. It is this main empirical question that I seek to address in this study.

A separate but complementary branch of analytical research examines the costs, especially the proprietary ones, associated with disclosures. Models such as Dye (1985), Verrecchia (1990), and Darrough and Stoughton (1990), argue that, all things being equal, the probability of disclosure decreases as the associated proprietary costs increase. Most of these proprietary costs borne by firms arise from interaction with other parties the costs of competitive disadvantage from disclosing information to their competitors and regulators, of bargaining disadvantages with both suppliers and consumers, and of litigation that might follow informative disclosure, are three such examples.

As Fields et al. (2001) suggest, most empirical studies to date do not consider the related costs of higher disclosure and reporting quality and whether these costs affect the disclosure and reporting decisions. Firms measure the valuation benefits of providing higher quality earnings against the associated costs. If the costs outweigh the market valuation benefits, the firm will choose to provide a lower quality of reported earnings, which will be less informative. This strongly motivates my examination of both the costs and benefits, among other firm-specific determinants, associated with disclosure policies.

\section{Research Design}

Firms' financial reporting quality policies are likely to be endogenous. If factors influencing cross-sectional variation in the reporting policies also influence the association between the economic consequences and the quality of the reported accounting information, failing to control for these factors may lead to erroneous inferences (Maddala, 1983). To address this issue, I use a two-stage estimation method (Wooldridge, 2002). I first discuss my empirical measures of reporting quality and then address the factors determining financial reporting quality and its economic consequences.

\subsection{Measurement of Financial Reporting Quality}

In order to measure financial reporting quality I use two related methods. Across these methods, the focus is on the association between accruals and cash flows. A larger deviation between accruals and cash flows is interpreted as lower quality of accounting information, reflecting higher information risk. The first method relies on the model presented in Barth et al. (2001) in which I run a regression of future operating cash 
flows on previous period earnings components. The first empirical measure of reporting quality is based on the residuals obtained from estimating the model specified in equation (1):

$$
\begin{aligned}
\mathrm{CFO}_{i, t+1}= & \alpha_{0}+\beta_{1} \mathrm{CFO}_{i, t}+\beta_{2} \Delta A R_{i, t}+\beta_{3} \Delta I N V_{i, t}+\beta_{4} \Delta A P_{i, t}+ \\
& \beta_{5} \mathrm{DEPR}_{i, t}+\beta_{6} \mathrm{OTHER}_{i, t}+\varepsilon_{i, t+1}
\end{aligned}
$$

Where, $C F O_{i, t}$ is cash flows from operations for firm i at year t (Compustat annual data item \#308) minus the accrual portion of extraordinary items and discontinued operations per the statement of cash flows (Compustat annual data item \#124); $\Delta A R_{i, t}$ is change in accounts receivable account per the statement of cash flows (Compustat annual data item \#302); $\Delta I N V_{i, t}$ is change in inventory account per the statement of cash flows (Compustat annual data item \#303); $\Delta A P_{i, t}$ is change in accounts payable and accrued liabilities account per the statement of cash flows (Compustat annual data item \#304); $D E P R_{i, t}$ is depreciation and amortization expense (Compustat annual data item \#125); $O T H E R_{i, t}$ is net of all other accruals, calculated as EARN - $(C F O+\triangle A R+\triangle I N V-$ $\triangle A P-D E P R)$, where $E A R N$ is income before extraordinary items and discontinued operations (Compustat annual data item \#18); all variables are deflated by average total assets.

In order to obtain the financial reporting quality metric, I estimate equation (1) for each fiscal year $t$ for each two-digit SIC industry code. The first empirical measure of reporting quality is the absolute value of the residuals obtained from (1): $F Q 1=\left|e_{i, t+1}\right|$. These residuals reflect the magnitude of future operating cash flows unrelated to current disaggregated earnings. In the empirical analysis that follows, I interpret lower absolute value as representing a higher quality of financial reporting, which corresponds to a higher level of cash flow predictability. The second empirical measure $F Q 2=\sigma\left(e_{i}\right)_{t}$ is the standard deviation of firm $i$ 's residuals calculated over years $t$-4 through $t$. A larger standard deviation of residuals indicates a lower quality of reported earnings.

To be consistent with current research, the second method of measuring reporting quality is based on the Dechow and Dichev (2002) method as implemented in Francis et al. (2005). Under this approach, reporting quality is measured by the extent to which working capital accruals map into cash flows realizations. I estimate the following regression for each year $t$ for each two-digit SIC code:

$$
\Delta W C_{i, t}=\gamma_{0}+\gamma_{1} C F O_{i, t-1}+\gamma_{2} C F O_{i, t}+\gamma_{3} C F O_{i, t+1}+\gamma_{4} \Delta R E V_{i, t}+\gamma_{5} P P E_{i, t}+\varepsilon_{i, t}
$$

Where, $\Delta W C_{i, t}$ is the change in working capital for firm $i$ at year $t$ which is computed as the change in accounts receivable (Compustat annual data item \#302) plus the change in inventory (Compustat annual data item \#303) less the change in accounts payable (Compustat annual data item \#304) less the change in taxes payable (Compustat annual data item \#305) plus the change in other net assets (Compustat annual data item \#307); $\triangle R E V_{i, t}$ is the change in sales revenues (Compustat annual data item \#12) between year $t-1$ and year $t ; P P E_{i, t}$ is gross value of property, plant and equipment (Compustat annual data item \#7) in year $t$; the absolute value of the residuals obtained from estimating equation (2) form the third measure of reporting quality: $F Q 3$, while $F Q 4$ is the standard deviation of the residuals obtained from estimating equation (2) calculated over years $t-4$ through $t$. 


\subsection{Determinants of Financial Reporting Quality}

The choice firms make about the quality of the financial information they report in their public financial statements reflects an analysis that weighs the expected benefits against the associated costs of reporting high-quality information. Given the expected benefits of providing information of higher quality, one would expect firms to choose to provide the highest quality of financial information possible, absent any costs of disclosing such information. Thus, one would expect to observe a corner solution where the maximum reporting quality is chosen. In reality, this does not occur, implying that there are costs associated with disclosure, such as direct costs (non-proprietary), litigation costs and proprietary costs. Given such costs, firms would select an interior solution to financial reporting quality. Therefore, when investigating the factors that determine a firm's reporting strategy decision, this trade-off has to be considered.

In addition to these specific factors affecting firms' financial reporting quality decisions, I rely on cross-sectional determinants of firms' disclosure policies used by prior literature (e.g., Lang and Lundholm, 1993, 1996, among others). These studies have provided evidence that disclosure decisions are associated with financing needs, the firm's information environment, incentive costs, firm performance, litigation costs and ownership dispersion. Building on these identified determinants, I present below the empirical model and outline the measures I use for firm-specific explanatory variables determining the variation in financial reporting quality.

In the first stage of the analysis, I estimate the following model based on the variables discussed below:

$$
\begin{aligned}
F Q_{i, t+1}= & \phi_{0}+\phi_{1} \mathrm{OWNER}_{i, t}+\phi_{2} \mathrm{GROWTH}_{i, t}+\phi_{3} \text { CAPITAL }_{i, t}+\phi_{4} A_{-} \text {HERF }_{i, t}+ \\
& \phi_{5} \operatorname{ISSUE}_{i, t}+\phi_{6} \mathrm{LIT}_{i, t}+\phi_{7} \mathrm{LEV}_{i, t}+\phi_{8} \text { MARGIN }_{i, t}+ \\
& \phi_{9} \mathrm{OC}_{i, t}+\phi_{10} N_{-} \mathrm{SEG}_{i, t}+\phi_{11} \operatorname{SIZE}_{i, t}+\phi_{12} \text { AGE }_{i, t}+\xi_{i, t+1}
\end{aligned}
$$

Where, $F Q_{i, t+1}$ is the financial reporting quality measure, as described in the previous section; $O W N E R_{i, t}$ is natural log of the number of shareholders of firm $i$ in year $\mathrm{t}$ (Compustat annual data item \#100) minus natural log of the mean number of shareholders in the firm's size decile; GROWTH ${ }_{i, t}$ is current year's growth in sales, calculated as net sales for year $t$ (Compustat annual data item \#12) less net sales of year $t-1$, scaled by net sales for year $t-1$; CAPITAL $L_{i, t}$ is net plant, property and equipment (Compustat annual data item \#8) divided by total assets (Compustat annual data item \#6) ${ }^{1}$; $A_{-} H E R F_{i, t}$ is the weighted (by segment sales) average HerfindahlHirschman Index for the industries in which firm $i$ reports business segment sales. The Herfindahl-Hirschman Index is calculated as the sum of squares of market shares in the industry. $\mathrm{HERF}=\sum_{\mathrm{i}=1}^{\mathrm{n}}\left[\mathrm{s}_{\mathrm{i}} / \mathrm{S}\right]^{2}$, where $s_{\mathrm{i}}$ is the firm's sales and $\mathrm{S}$ is the sum of sales for all firms in the industry (defined by the two-digit SIC code), and $\mathrm{n}$ is the number of firms in the industry; ISSUE $E_{i, t}$ is a dummy variable equal to one if the company

\footnotetext{
${ }^{1}$ When the reporting quality measure is $F Q 3$ and $F Q 4$, I do not include the variables CAPITAL and MARGIN as a determinant to avoid any mechanical association given that PPE and a variation of MARGIN is used as an explanatory variable in equation (2).
} 
issued debt or equity during the current fiscal year or the next two fiscal years, and zero otherwise; $L I T_{i, t}$ is a dummy variable equal to one if the firm is in a "highlitigation" industry, zero otherwise ${ }^{2} ; L E V_{i, t}$ is long-term debt (Compustat annual data item \#9) plus debt in current liabilities (Compustat annual data item \#34) divided by firm value (Compustat annual data item \#199 times Compustat annual data item \#25); MARGIN $_{i, t}$ is gross margin percentage, calculated as the year $t$ net sales (Compustat annual data item \#12) less cost of goods sold for the year (Compustat annual data item \#41), scaled by net sales; $O C_{i, t}$ is operating cycle for firm $i$ at time $t$, measured in days as $\frac{\left(A R_{t}+A R_{t-1}\right) / 2}{(\text { Sales/360) }}+\frac{\left(I N V_{t}+I N V_{t-1}\right) / 2}{(\mathrm{COGS} / 360)}$, where $A R$ is the firm's accounts receivable, $I N V$ is the firm's inventory, and COGS is the firm's cost of goods sold; $N \_S E G_{i, t}$ are the number of two-digit SIC code industries that the firm is engaged in year $t ; S I Z E_{i, t}$ is the natural logarithm of market capitalization at the end of the fiscal year (year $t$ ), calculated as the closing price at fiscal year-end times the number of shares outstanding at fiscal year-end (Compustat annual data item \#199 times Compustat annual data item \#25); $A G E$ is the firm's age defined as natural logarithm of number of months the company has been listed on CRSP. I estimate the model in equation (3) both across firms and time, resulting in a pooled cross-sectional time-series specification.

Firms have incentives to respond to investors' demands for firm-specific information since reducing information asymmetries between the firm and its investors can lower their cost of capital (Healy and Palepu, 2001). External demands for firm-specific financial information are expected to vary with the level of ownership concentration. Higher potential information asymmetry, especially among investors, and demands for firm-specific information are expected for firms with a highly-dispersed investor base. Therefore, outsiders' demands for financial information from these firms is expected to be higher than for firms with high levels of ownership holdings. To capture the effect of ownership dispersion on the quality of financial reporting, I use the variable $O W N E R$, which is the log of the number of shareholders of the firm adjusted by the log of the mean number of shareholders in the firm's size decile.

To proxy for the proprietary costs associated with the reporting decision, I use measures of a firm's capital intensity, growth opportunities, and characteristics of its product market. If a product market's barriers to entry are relatively high, the associated costs of disclosure should be relatively low. High capital intensity is generally interpreted as a major barrier to entry. Therefore, capital intensity is thought to be positively associated with the quality of financial information. High entry costs to a market, as reflected by high capital requirements, create situations in which a large fraction of the capital costs are already sunk for incumbent firms, but are decisionrelevant to potential entrants. To capture the feature of capital intensity as a barrier to entry, I use the variable CAPITAL, which comprises net property, plant and equipment scaled by total assets. Capital intensity proxies also for financing needs (Leuz and Verrecchia, 2000), thus, consistent with the literature to date, it is expected that more

2 Following Kasznik and Lev (1995), I define "high-litigation" industry as: high-technology firms (SIC codes 2833-2836, 8731-8734, 7371-7379, 3570-3577, 3600-3674). 
capital-intense firms which have higher financing needs will provide higher quality of financial information.

Another measure of proprietary costs relates to the firm's growth opportunities. The more innovative a market is and the more heavily it relies on intangible knowledge, the more a firm should invest to retain its unique status and preserve future opportunities. Given that these future opportunities are positively associated with proprietary costs, I use GROWTH, which I define as the current year's percentage change in sales, as a proxy for future opportunities that the firm needs to protect. I expect that it will be negatively associated with financial reporting quality.

The literature identifies existing competition in a firm's product market as being associated with proprietary costs. Competition thus influences a firm's disclosure decisions. In order to account for product market competition, I measure the concentration rate of each industry using the Herfindahl-Hirschman Index as defined above.

To be consistent with the literature that suggests that performance is an important determinant of disclosures (e.g., Lang and Lundholm, 1993), I include the variable MARGIN, defined as sales revenue net of cost of goods sold, scaled by net sales. Litigation costs have been suggested by prior studies (e.g., Lev and Kasznik, 1995) as a determining factor of financial reporting strategies. I define the dummy variable LIT to take the value of 1 if the firm operates in a "high-litigation" risk industry. If lower precision of accounting information is costly to firms, I expect that when litigation costs are higher, the quality of information is higher.

The presence of agency costs gives rise to demand for monitoring, and the information a firm's financial statements provide may be used to mitigate agency costs (Jensen and Meckling, 1976). Highly leveraged firms have higher agency costs and thus a greater demand for monitoring. Therefore, I predict reporting quality to vary with a firm's capital structure. I use the variable $L E V$, which is the firm's total debt to firm value, to capture this determinant of financial reporting quality.

Motivated by the empirical evidence in prior research that security issuance is associated with disclosure policies (e.g., Lang and Lundholm, 1993), I include the variable ISSUE as an additional determinant of financial reporting quality. In addition, I also control for the firm's informational environment by including the firm's size, as defined above. The variable $A G E$ is included, conjecturing that younger firms have a lower quality of accounting information. Following Dechow and Dichev (2002), I also control for the firm's operating cycle, $O C$, as defined above.

\subsection{Economic Consequences of Financial Reporting Quality}

I use three proxies for capital markets consequences of financial reporting quality: 1. the firm's cost of equity capital, 2. the firm's standard deviation of stock returns, and 3. the firm's idiosyncratic risk, estimated as the residual variance from a regression of stock returns on the market's return. The main hypothesis that I test is whether providing financial information of higher quality is associated with capital markets valuation benefits. As noted before, I estimate a two-stage procedure (Wooldridge, 2002) in the first stage of which I estimate a financial reporting quality model. Using the fitted values 
from the first stage model as an instrumental variable for the financial reporting quality measure (IV), I estimate in the second stage an OLS regression of capital markets/ valuation benefits proxies on firm characteristics and this instrumental variable.

\subsection{Financial Reporting Quality and Risk}

\subsubsection{Cost of Equity Capital}

In Francis et al. (2004, 2005), lower quality financial reporting leads to greater uncertainty and ultimately to higher information risk. If this risk cannot be diversified away, it will result in a higher cost of equity capital. Following this rationale, I test the association between the empirical measures of reporting quality outlined in section 3.2 and an implied equity cost of capital estimated using the models presented in Claus and Thomas (2001), Gebhardt et al. (2001), Ohlson and Juettner-Nauroth (2005) as implemented in Gode and Mohanram (2003), and Easton (2004). I average the four proxies to reduce any measurement error in the equity cost of capital proxies and use $R_{A V G}$ as the main economic consequence variable. ${ }^{3}$ In addition to the four implied equity cost of capital estimates, as a sensitivity test, I use a stock-return metric based on the Fama-French three-factor model. Due to the lack of consensus in the literature as to which measure is the best, or even whether these empirical proxies can be evaluated, I believe that using this variety of procedures ensures the reader that the results documented in the study are robust and convincing.

\subsubsection{Standard Deviation of Stock Returns}

Standard deviation of stock returns is a commonly used measure of risk in the literature. Stock price volatility has been identified as a proxy for uncertainty and information asymmetry between the firm and its shareholders and among capital markets participants (e.g., Lang and Lundholm, 1993). High levels of uncertainty and information asymmetries suggest higher levels of volatility, i.e., higher standard deviation of stock returns. Analytical research has shown that, in addition to the release of public financial information, the quality of disclosures affects the levels of uncertainty and information asymmetry in the capital markets (e.g., Diamond and Verrecchia, 1991). I measure volatility as the standard deviation of daily stock returns calculated over the 12 months following June of year $t$.

\subsubsection{Idiosyncratic Risk}

The standard deviation of stock returns is a measure of total risk, which includes both systematic and idiosyncratic components. Stock returns which are tied to common factors or marketwide returns are the source of systematic risk. Unsystematic or idiosyncratic risk results from innovations that are specific to a particular stock. I assume, consistent with the asset-pricing literature, that the return on every stock is

\footnotetext{
${ }^{3}$ Furthermore, I have performed the analysis using the four individual models and obtained very similar results to the one I report. These results are available from the author by request.
} 
driven by a common factor and a firm-specific component $\varepsilon_{i}$. Assuming a simple market model in the return-generating equation one gets:

$$
R_{i, t}-r_{f, t}=\beta_{i}\left(R_{m, t}-r_{f, t}\right)+\varepsilon_{i, t}
$$

where $R_{i, t}$ is the return on stock $i, R_{m, t}$ is the market return, $r_{f, t}$ is the risk-free rate, and $\varepsilon_{i, t}$ is the idiosyncratic return. The CAPM implies that investors can earn the risk-free rate by investing in a risk-free asset and $\beta_{i}\left(R_{m, t}-r_{f, t}\right)$ is the required risk premium for asset $i$. Since $\beta_{i}\left(R_{m, t}-r_{f, t}\right)$ is common to all the assets in the economy, $\beta_{i}$ is the only factor specific to asset $i$ determining the expected rate of return and thus the required risk premium. The CAPM does not account for the component $\sigma_{\varepsilon_{i}}^{2}$ and suggests that this idiosyncratic risk does not affect risk premiums since in an economy with a large number of assets, it can be diversified away by holding a well-diversified portfolio. ${ }^{4}$

I define idiosyncratic risk, IDIOS, as the residual variance from a firm-specific regression of stock returns on the CRSP value-weighted market index over a 12-month period.

\section{Data and Empirical Results}

\subsection{Sample Selection}

I base my analysis on data obtained from the following sources: the 2004 Compustat annual industrial and research files, the 2004 CRSP files, and I/B/E/S data for 19872003. I use the 1987-2003 period since cash flow from operations (Compustat annual data item \#308) calculated from the statement of cash flows only becomes available in 1987, following SFAS No. 95.

I exclude firms in SIC codes 6000-6999 (financial institutions, insurance, and real estate companies) since the cash flow predictability empirical model developed does not reflect their activities. Next, I restrict the analysis to firms that do not have any missing data for the variables used in the empirical analysis, and I exclude observations with the most extreme one percent value of their distributions. ${ }^{5}$ I require that each firm has at least one year of past and future cash flow from operations. These criteria yield a primary sample of 18,264 firm-year observations, representing 2,857 firms.

\subsection{Descriptive Statistics}

Table 1, Panel A, reports summary statistics of the reporting quality measures for the sample of firms. Given that all the reporting quality metrics capture variation in components of accruals, it is not surprising that all the metrics have similar mean and

\footnotetext{
${ }^{4}$ I have repeated the analysis assuming the Fama-French three-factor model as the relevant asset-pricing model as an alternative to the CAPM and focused on the firm-specific idiosyncratic component under this specification. The reported results and interpretations in the paper are not affected by this alternative method.

${ }^{5}$ The results and inferences reported are not affected by eliminating the extreme values of the distribution.
} 
median values. ${ }^{6}$ Consistent with findings in Gebhardt et al. (2001) that implied cost of equity capital estimates based on accounting valuation models are lower than estimates based on ex post stock returns, the estimates based on the Fama-French three-factor model are higher than the implied based estimates. ${ }^{7}$

Table 1

\section{Descriptive Statistics}

This table presents descriptive statistics for the total sample of 18,264 firm-year observations.

Panel A: Financial Reporting Quality Metrics

\begin{tabular}{|l|c|c|c|}
\hline & Mean & Median & Std. Dev. \\
\hline $\boldsymbol{F Q 1}$ & 0.0551 & 0.0362 & 0.064 \\
\hline $\boldsymbol{F Q 2}$ & 0.0487 & 0.0341 & 0.052 \\
\hline $\boldsymbol{F Q 3}$ & 0.0614 & 0.0484 & 0.058 \\
\hline $\boldsymbol{F Q 4}$ & 0.0511 & 0.0389 & 0.067 \\
\hline
\end{tabular}

Panel B: Descriptive Statistics of Equity Cost of Capital Estimates

\begin{tabular}{|c|c|c|c|}
\hline & Mean (\%) & Median (\%) & Std. Dev. (\%) \\
\hline $\boldsymbol{R}_{O J}$ & 13.1 & 12.7 & 3.68 \\
\hline $\boldsymbol{R}_{P E G}$ & 11.8 & 10.4 & 3.25 \\
\hline $\boldsymbol{R}_{G L S}$ & 10.9 & 9.7 & 2.98 \\
\hline $\boldsymbol{R}_{C T}$ & 11.1 & 10.8 & 2.84 \\
\hline $\boldsymbol{R}_{\text {AVG }}$ & 12.3 & 10.5 & 3.11 \\
\hline $\boldsymbol{R}_{F F}$ & 15.4 & 14.2 & 2.18 \\
\hline
\end{tabular}

Panel C: Descriptive Statistics for Sample Firms

\begin{tabular}{|l|c|c|c||}
\hline Variable & Mean & Median & Std. Dev. \\
\hline SIZE (\$mil) & 1756.82 & 278.37 & 4856.72 \\
\hline ASSETS (\$mil) & 1549.42 & 238.42 & 3865.49 \\
\hline ROA & 0.018 & 0.038 & 0.167 \\
\hline GROWTH & 0.068 & 0.059 & 0.321 \\
\hline A_HERF & 0.281 & 0.253 & 0.107 \\
\hline LEV & 0.173 & 0.154 & 0.182 \\
\hline OC (days) & 138.12 & 126.70 & 76.70 \\
\hline N_SEG & 2.86 & 1.00 & 2.81 \\
\hline DISP & 0.0139 & 0.0062 & 0.032 \\
\hline
\end{tabular}

${ }^{6}$ Pairwise correlations (untabulated) suggest that the empirical measures of reporting quality are highly and significantly positively correlated.

${ }^{7}$ The (untabulated) correlations between the equity cost of capital estimates are consistent with the evidence presented in Gode and Mohanram (2003) and provide evidence that the four proxies are highly and significantly correlated. This is not surprising since the models rely on similar valuation inputs and constructs. 
Notes to Table 1:

$F Q 1=$ absolute value of residuals estimated using Barth et al. (2001) model; $F Q 2=$ standard deviation of residuals estimated using Barth et al. (2001) model calculated over years $t-4$ through $t ; F Q 3=$ absolute value of residuals estimated using a modified Dechow and Dichev (2002) model as implemented in Francis et al. (2004, 2005); FQ4 = standard deviation of residuals estimated using a modified Dechow and Dichev (2002) model as implemented in Francis et al. $(2004,2005)$ calculated over years $t-4$ through $t ; R_{O J}=$ Equity cost of capital based on the Ohlson and Juettner-Nauroth (2005) approach; $R_{P E G}=$ Equity cost of capital based on the PEG ratio model of Easton (2004); $R_{G L S}=$ Equity cost of capital based on Gebhardt, Lee and Swaminathan (2001); $R_{C T}=$ Equity cost of capital based on Claus and Thomas (2001); $R_{A V G}=$ The average of the four implied equity cost of capital estimates; $R_{F F}=$ Expected return calculated using Fama and French three-factor model; SIZE $=$ Natural logarithm of market capitalization at the end of the fiscal year (year $t$ ), calculated as the closing price at fiscal year-end times the number of shares outstanding at fiscal year-end (Compustat annual data item \#199 times Compustat annual data item \#25); ASSETS = Total assets (Compustat annual data item \#6); ROA = Return on assets, defined as EARN (Compustat annual data item \#18) divided by total assets (Compustat annual data item \#6); GROWTH = Current year's growth in sales, calculated as net sales for year $t$ (Compustat annual data item \#12) less net sales of year $t-1$, scaled by net sales for year $t-1 ; A \_H E R F=$ The weighted (by segment sales) average Herfindahl-Hirschman Index for the industries in which firm $i$ reports business segment sales. The Herfindahl-Hirschman Index is calculated as the sum of squares of market shares in the industry: $H E R F=\sum_{i=1}^{n}\left[s_{i} / S\right]^{2}$, where $S_{i}$ is the firm's sales and $S$ is the sum of sales for all firms in the industry (defined by the two-digit SIC code), and $n$ is the number of firms in the industry. $L E V=$ Long term debt (Compustat annual data item \#9) plus debt in current liabilities (Compustat annual data item \#34) divided by firm value (Compustat annual data item \#199 times Compustat annual data item \#25); OC = Operating Cycle (in days); $N \_S E G=$ Number of two-digit SIC code industries that the firm is engaged in; DISP $=$ Standard deviation of analysts' forecasts of year $t$ earnings per share (IBES) for firm $i$, measured in June following fiscal year $t-1$, scaled by beginning of period price.

An examination of the descriptive statistics reported in Table 1, Panel C, suggests that the sample firms are large relative to the Compustat population, with mean (median) total assets of $\$ 1,549$ million ( $\$ 238$ million) and mean (median) market value of equity of $\$ 1,756$ million ( $\$ 278$ million), profitable (return on assets of about 0.018 ), and growing (median sales growth of 0.068 ). The operating cycle $(O C)$ has a mean of 138 days and a standard deviation of 77 days. This indicates that the majority of the firms in the sample have an operating cycle of less than one year. This finding is consistent with the fact that most accruals reverse within one year (Dechow and Dichev, 2002). The mean (median) of $A \_H E R F$ (the concentration ratio) is $0.28(0.25)$, indicating that the sample represents rather competitive industries. 


\subsection{Multivariate Analysis - Determinants of Financial Reporting Quality}

Table 2

Determinants of Firms' Financial Reporting Quality

$$
\begin{aligned}
& F Q_{i, t+1}=\phi_{0}+\phi_{1} \mathrm{OWNER}_{i, t}+\phi_{2} \mathrm{GROWTH}_{i, t}+\phi_{3} \text { CAPITAL }_{i, t}+\phi_{4} A_{-} \text {HERF }_{i, t}+\phi_{5} \text { ISSUE }_{i, t}+\phi_{6} \text { LIT }_{i, t}+ \\
& +\phi_{7} \text { LEV }_{i, t}+\phi_{8} \text { MARGIN }_{i, t}+\phi_{9} \text { OC }_{i, t}+\phi_{10} N_{-} \text {SEG }_{i, t}+\phi_{11} \operatorname{SIZE}_{i, t}+\phi_{12} A G E_{i, t}+\xi_{i, t+1}
\end{aligned}
$$

\begin{tabular}{|c|c|c|c|c|c|}
\hline Variable & Pred. & $F Q 1$ & $F Q 2$ & $F Q 3$ & $F Q 4$ \\
\hline$O W N E R$ & - & $\begin{array}{l}-0.0092 \\
(-20.37)\end{array}$ & $\begin{array}{l}-0.0084 \\
(-12.54)\end{array}$ & $\begin{array}{l}-0.0075 \\
(-11.32)\end{array}$ & $\begin{array}{c}-0.0054 \\
(-8.54)\end{array}$ \\
\hline GROWTH & + & $\begin{array}{c}0.0001 \\
(2.15)\end{array}$ & $\begin{array}{c}0.0001 \\
(1.47)\end{array}$ & $\begin{array}{c}0.0000 \\
(0.94)\end{array}$ & $\begin{array}{c}0.0000 \\
(1.21)\end{array}$ \\
\hline CAPITAL & - & $\begin{array}{l}-0.0445 \\
(-18.29)\end{array}$ & $\begin{array}{l}-0.0342 \\
(-15.68)\end{array}$ & & \\
\hline A_HERF & $?$ & $\begin{array}{c}0.0089 \\
(3.20)\end{array}$ & $\begin{array}{c}0.0074 \\
(2.99)\end{array}$ & $\begin{array}{c}0.0068 \\
(3.32)\end{array}$ & $\begin{array}{c}0.0054 \\
(3.53)\end{array}$ \\
\hline ISSUE & - & $\begin{array}{l}-0.0021 \\
(-8.67)\end{array}$ & $\begin{array}{c}-0.0045 \\
(-5.45)\end{array}$ & $\begin{array}{c}-0.0035 \\
(-4.98)\end{array}$ & $\begin{array}{r}-0.0027 \\
(-5.21)\end{array}$ \\
\hline$L I T$ & - & $\begin{array}{c}-0.0001 \\
(-0.95)\end{array}$ & $\begin{array}{c}-0.0000 \\
(-0.54)\end{array}$ & $\begin{array}{c}-0.0000 \\
(-0.41)\end{array}$ & $\begin{array}{c}-0.0002 \\
(-1.02)\end{array}$ \\
\hline$L E V$ & - & $\begin{array}{c}-0.0051 \\
(-6.58)\end{array}$ & $\begin{array}{c}-0.0048 \\
(-7.98)\end{array}$ & $\begin{array}{c}-0.0056 \\
(-8.65)\end{array}$ & $\begin{array}{r}-0.0047 \\
(-5.21)\end{array}$ \\
\hline MARGIN & $+/-$ & $\begin{array}{l}0.2631 \\
(30.64)\end{array}$ & $\begin{array}{l}0.1253 \\
(12.51)\end{array}$ & & \\
\hline$O C$ & + & $\begin{array}{c}0.0001 \\
(5.25)\end{array}$ & $\begin{array}{c}0.0000 \\
(3.14)\end{array}$ & $\begin{array}{c}0.0000 \\
(2.98)\end{array}$ & $\begin{array}{c}0.0001 \\
(3.25)\end{array}$ \\
\hline N_SEG & $?$ & $\begin{array}{c}0.0012 \\
(1.24)\end{array}$ & $\begin{array}{c}0.0001 \\
(0.75) \\
\end{array}$ & $\begin{array}{c}0.0001 \\
(0.65) \\
\end{array}$ & $\begin{array}{c}0.0000 \\
(0.24)\end{array}$ \\
\hline$S I Z E$ & - & $\begin{array}{c}-0.0025 \\
(-3.84) \\
\end{array}$ & $\begin{array}{c}-0.0005 \\
(-6.54) \\
\end{array}$ & $\begin{array}{c}-0.0004 \\
(-5.68) \\
\end{array}$ & $\begin{array}{c}-0.0002 \\
(-5.21) \\
\end{array}$ \\
\hline$A G E$ & - & $\begin{array}{l}-0.0014 \\
(-1.35)\end{array}$ & $\begin{array}{c}-0.0001 \\
(-0.85)\end{array}$ & $\begin{array}{c}-0.0001 \\
(-0.74)\end{array}$ & $\begin{array}{c}-0.0001 \\
(-1.88)\end{array}$ \\
\hline$R^{2}$ & & 0.38 & 0.45 & 0.48 & 0.49 \\
\hline
\end{tabular}

T-statistics are reported in parentheses.

$F Q 1$ = absolute value of residuals estimated using Barth et al. (2001) model; $F Q 2$ = standard deviation of residuals estimated using Barth et al. (2001) model calculated over years $t$-4 through $t ; F Q 3=$ absolute value of residuals estimated using a modified Dechow and Dichev (2002) model as implemented in Francis et al. (2004, 2005); FQ4 = standard deviation of residuals estimated using a modified Dechow and Dichev (2002) model as implemented in Francis et al. $(2004,2005)$ calculated over years $t$-4 through $t$.

As discussed in section 3, I first examine the determinants of reporting quality. The results of a multivariate analysis from estimating the model specified in equation (3) using the different quality measures are reported in Table 2. I interpret the significance of $O W N E R$ as consistent with investors' demands for financial information influencing the quality of this information. Firms that are more leveraged ( $L E V)$ are significantly 
more likely to provide high-quality financial information. This is consistent with debt contracting and monitoring influencing the quality of financial information.

In addition, I find evidence that proprietary costs affect the reporting quality choice. In particular, the results indicate that the overall competition the firm faces measured by $A \_H E R F$ (the weighted Herfindahl-Hirschman Index), affects reporting quality. The coefficients of $A_{-} H E R F$ are significantly positive, suggesting that firms in less competitive industries are less likely to report high-quality information. This result is consistent with the findings in Harris (1998), who demonstrates that firms are less likely to disclose operations in less competitive industries as business segments. In other words, a higher quality of information prevails in more competitive environments.

CAPITAL has a significant positive effect on reporting quality, which suggests that more capital-intensive firms provide financial information that more precisely predicts future cash flows. One explanation for this finding is that capital intensity acts as a barrier to entry for future competitors in the product market. Therefore, such firms incur fewer costs in providing financial information which is more informative regarding future performance. In addition, CAPITAL proxies for financing needs. This suggests that more capital-intense firms have more financing needs, inducing a higher quality of information. Consistent with Lang and Lundholm (1993), I find that firms that are more active in issuing securities choose to provide high-quality information. The variable $I S S U E$ is positively associated with the quality of financial information provided. The coefficient on GROWTH is significant at conventional levels only when the dependent quality variable is $F Q 1$.

The results indicate that the larger the firm, the higher the quality of its financial reporting. This finding is consistent with previous research documenting a positive relation between firm size and disclosure policy decisions (e.g., Lang and Lundholm, 1993). The significant coefficient on MARGIN bears out the hypothesis that more profitable firms (as reflected in higher realized margins) have the higher proprietary costs associated with lower reporting quality.

The litigation variable $(L I T)$ is not significant at conventional levels, suggesting that it is not associated with the quality of financial information. One explanation for this finding is due to the nature of the quality measure which proxies for precision of information, rather than the specific type of information, i.e., good news versus bad news (see Kasznik and Lev, 1995). The coefficient on $O C$ is positive and significant across all the model specifications in Table 2, consistent with the evidence in Dechow and Dichev (2002). This implies that firms with higher operating cycles have lower quality of financial reporting. The control variable $A G E$ is in general not significant in explaining variation in quality choices.

\subsection{Economic Consequences of Financial Reporting Quality}

In this section, I examine the capital markets consequences associated with financial reporting quality policies. First, for each one of the specifications, I estimate an OLS regression, treating reporting quality as exogenous. Next, I use the instrumental variables from the first stage as proxies for reporting quality and repeat the analysis. Such an analysis examines whether information risk is associated with any of the 
economic consequences variables once the specific factors determining this information risk are modeled and controlled for.

Table 3

Association between Equity Cost of Capital and Reporting Quality

$$
\begin{aligned}
R_{A V G}= & \rho_{0}+\rho_{1} \text { BETA }_{i, t}+\rho_{2} \operatorname{SIZE}_{i, t}+\rho_{3} L E V_{i, t}+\rho_{4} \operatorname{DISP}_{i, t}+\rho_{5} L T G_{i, t}+ \\
& \rho_{6} B_{-} M_{i, t}+\rho_{7} \operatorname{INDS}_{i, t}+\rho_{8} F Q_{i, t}+\vartheta_{i, t}
\end{aligned}
$$

\begin{tabular}{|c|c|c|c|c|c|c|c|c|}
\hline Variable & $\begin{array}{c}F Q 1 \\
(1)\end{array}$ & $\begin{array}{c}F Q 2 \\
(2)\end{array}$ & $\underset{(\mathbf{3})}{F Q 3}$ & $\begin{array}{c}F Q 4 \\
(4)\end{array}$ & $\begin{array}{c}I V 1 \\
(5)\end{array}$ & $\begin{array}{c}I V 2 \\
(6)\end{array}$ & $\begin{array}{l}I V 3 \\
(7)\end{array}$ & $\begin{array}{c}I V 4 \\
(8)\end{array}$ \\
\hline BETA & $\begin{array}{l}0.021 \\
(2.76)\end{array}$ & $\begin{array}{l}0.025 \\
(2.18)\end{array}$ & $\begin{array}{l}0.019 \\
(2.11)\end{array}$ & $\begin{array}{l}0.020 \\
(2.15)\end{array}$ & $\begin{array}{l}0.023 \\
(2.64)\end{array}$ & $\begin{array}{l}0.027 \\
(2.21)\end{array}$ & $\begin{array}{l}0.021 \\
(2.08)\end{array}$ & $\begin{array}{l}0.023 \\
(2.32)\end{array}$ \\
\hline SIZE & $\begin{array}{l}-0.041 \\
(-3.87) \\
\end{array}$ & $\begin{array}{l}-0.039 \\
(-3.72) \\
\end{array}$ & $\begin{array}{l}-0.037 \\
(-3.69) \\
\end{array}$ & $\begin{array}{l}-0.040 \\
(-3.65) \\
\end{array}$ & $\begin{array}{l}-0.039 \\
(-3.75) \\
\end{array}$ & $\begin{array}{l}-0.036 \\
(-3.62) \\
\end{array}$ & $\begin{array}{l}-0.034 \\
(-3.55) \\
\end{array}$ & $\begin{array}{r}-0.036 \\
(-3.47) \\
\end{array}$ \\
\hline$L E V$ & $\begin{array}{l}0.054 \\
(6.25)\end{array}$ & $\begin{array}{l}0.049 \\
(5.87)\end{array}$ & $\begin{array}{l}0.044 \\
(5.42)\end{array}$ & $\begin{array}{l}0.035 \\
(4.99)\end{array}$ & $\begin{array}{l}0.051 \\
(6.31)\end{array}$ & $\begin{array}{l}0.047 \\
(5.16)\end{array}$ & $\begin{array}{l}0.041 \\
(5.11)\end{array}$ & $\begin{array}{l}0.029 \\
(3.99)\end{array}$ \\
\hline DISP & $\begin{array}{l}-0.071 \\
(-4.85) \\
\end{array}$ & $\begin{array}{l}-0.068 \\
(-4.88) \\
\end{array}$ & $\begin{array}{l}-0.077 \\
(-5.01) \\
\end{array}$ & $\begin{array}{l}-0.061 \\
(-4.62) \\
\end{array}$ & $\begin{array}{l}-0.065 \\
(-3.96) \\
\end{array}$ & $\begin{array}{l}-0.054 \\
(-3.52) \\
\end{array}$ & $\begin{array}{l}-0.071 \\
(-4.67) \\
\end{array}$ & $\begin{array}{l}-0.071 \\
(-4.27) \\
\end{array}$ \\
\hline$L T G$ & $\begin{array}{c}0.54 \\
(3.85)\end{array}$ & $\begin{array}{c}0.48 \\
(3.24)\end{array}$ & $\begin{array}{c}0.44 \\
(4.01)\end{array}$ & $\begin{array}{c}0.51 \\
(4.98)\end{array}$ & $\begin{array}{c}0.58 \\
(4.03)\end{array}$ & $\begin{array}{c}0.51 \\
(3.55)\end{array}$ & $\begin{array}{c}0.42 \\
(4.15)\end{array}$ & $\begin{array}{c}0.48 \\
(4.53)\end{array}$ \\
\hline$B \_M$ & $\begin{array}{c}0.85 \\
(6.45)\end{array}$ & $\begin{array}{c}0.75 \\
(6.57)\end{array}$ & $\begin{array}{c}0.81 \\
(7.12)\end{array}$ & $\begin{array}{c}0.76 \\
(6.98)\end{array}$ & $\begin{array}{c}0.81 \\
(6.12)\end{array}$ & $\begin{array}{c}0.72 \\
(6.08)\end{array}$ & $\begin{array}{c}0.83 \\
(6.58)\end{array}$ & $\begin{array}{c}0.71 \\
(6.72)\end{array}$ \\
\hline INDS & $\begin{array}{c}0.51 \\
(9.52)\end{array}$ & $\begin{array}{c}0.48 \\
(8.48)\end{array}$ & $\begin{array}{c}0.45 \\
(8.55)\end{array}$ & $\begin{array}{c}0.39 \\
(7.52)\end{array}$ & $\begin{array}{c}0.53 \\
(9.21)\end{array}$ & $\begin{array}{c}0.47 \\
(8.79)\end{array}$ & $\begin{array}{c}0.44 \\
(9.01)\end{array}$ & $\begin{array}{c}0.42 \\
(8.01)\end{array}$ \\
\hline$F Q 1$ & $\begin{array}{l}0.0051 \\
(3.08)\end{array}$ & & & & $\begin{array}{l}0.021 \\
(0.80)\end{array}$ & & & \\
\hline$F Q 2$ & & $\begin{array}{c}0.0042 \\
(2.98)\end{array}$ & & & & $\begin{array}{l}0.025 \\
(0.98)\end{array}$ & & \\
\hline$F Q 3$ & & & $\begin{array}{c}0.0039 \\
(2.78)\end{array}$ & & & & $\begin{array}{l}0.020 \\
(0.87)\end{array}$ & \\
\hline$F Q 4$ & & & & $\begin{array}{c}0.0044 \\
(3.68)\end{array}$ & & & & $\begin{array}{l}0.031 \\
(1.01)\end{array}$ \\
\hline $\begin{array}{l}\text { Mean Adj. } \\
\mathbf{R}^{2}\end{array}$ & 0.45 & 0.52 & 0.51 & 0.48 & 0.45 & 0.52 & 0.51 & 0.48 \\
\hline
\end{tabular}

T-statistics are reported in parentheses.

Table 3 reports mean coefficients and corresponding t-statistics (corrected for serial-correlation) from yearly OLS regressions.

The dependent variable is $R_{A V G}=$ the average of the four implied equity cost of capital estimates.

$F Q 1$ = absolute value of residuals estimated using Barth et al. (2001) model; $F Q 2=$ standard deviation of residuals estimated using Barth et al. (2001) model calculated over years $t-4$ through $t ; F Q 3=$ absolute value of residuals estimated using a modified Dechow and Dichev (2002) model as implemented in Francis et al. (2004, 2005); FQ4 = standard deviation of residuals estimated using a modified Dechow and Dichev (2002) model as implemented in Francis et al. (2004, 2005) calculated over years $t$-4 through $t$; IV1 - IV4 are instrumental variables based on $F Q 1-F Q 4$ respectively.

\subsubsection{Equity Cost of Capital}

Table 3 presents the results of examining whether reporting quality explains the variation in firm-specific equity cost of capital estimates. Replicating prior studies' 
findings, the first four columns report the results of the pricing effects of information quality, using $F Q 1-F Q 4$ as the empirical proxies. All four earnings quality metrics are significantly associated with the equity cost of capital after controlling for other factors associated with the equity cost of capital as identified in the accounting and finance literature. These results imply that firms providing high-quality accounting information enjoy a lower equity cost of capital. Based on these results, one could conclude that the reporting quality is an information risk factor which is systematically priced by capital markets participants, over and beyond additional risk factors priced by the market, such as beta, size, and book-to-market.

The results documented in the last four columns of Table 3, however, suggest that this conclusion does not hold up when one acknowledges the firm-specific factors affecting financial reporting quality. If the specification estimated using $F Q 1-F Q 4$ is subject to a correlated omitted variables problem, the estimated value of the coefficient corresponding to the particular treatment effect may be biased and inconsistent. Once all these factors are controlled for, the reporting quality coefficients are not significant (the coefficients on the instrumental variables $I V 1-I V 4$ decrease and approach zero) in explaining the cross-sectional variation in the equity cost of capital estimates over and above previously documented risk factors which influence the equity cost of capital. These findings suggest that lower financial reporting quality does not necessarily result in a significant higher cost of equity capital, once the firm-specific characteristics determining reporting quality have been accounted for. The above analysis demonstrates the importance of accounting for the underlying factors affecting variation in financial reporting quality. Failing to do so significantly affects the conclusions researchers draw from empirical analyses.

To address concerns regarding the validity of the implied equity cost of capital estimates, I also estimated the equity cost of capital using the Fama and French (1993) three-factor model, where the size factor is defined as small minus large firm returns $S M L$, the book-to-market factor is defined as high minus low book-to-market firm returns $H M L$, and the market factor is defined as the excess return on the CRSP valueweighted portfolio $\left(R_{m}-R_{f}\right)$. I obtain monthly time-series returns on the three factors, $S M L, H M L, \mathrm{R}_{m}-\mathrm{R}_{f}$ from Kenneth French's website. The loadings on the factors, $b, s$ and $h$, are slope coefficients estimated from the following regression model for firm $i$ :

$$
E\left(R_{F F}\right)=R_{f 0}+b_{0}\left[R_{m}-R_{f}\right]+s_{0} S M L+h_{0} H M L
$$

I re-estimate the three-factor model each year for each firm using a rolling window of five years of monthly returns ending in the month of June. Firm $i$ 's estimated loadings, i.e. estimated $b, s$ and $h$ coefficients, multiplied by the average returns for the three factors provide the equity cost of capital estimate for the firm $i$. Next, I annualize this number which is an equity cost of capital proxy as of the month of June. This consists of the fifth proxy for the equity cost of capital. Finally, I estimate the following regression ${ }^{8}$ :

$$
R_{F F_{i, t}}=\rho_{0}+\rho_{1} B E T A_{i, t}+\rho_{1} S I Z E+\rho_{3} B_{-} M_{i, t}+\rho_{4} F Q_{i, t}+\vartheta_{i, t}
$$

\footnotetext{
${ }^{8}$ This particular specification was used by Easley et al. (2002, equation (7), p. 2210) in determining the effect of information-based trading on asset returns.
} 
Table 4

Asset-Pricing Tests of Financial Reporting Quality: Association between Fama-French Three-Factor Model Estimates and Reporting Quality

$$
R_{F F i, t}=\rho_{0}+\rho_{1} B E T A_{i, t}+\rho_{1} S I Z E+\rho_{3} B_{-} M_{i, t}+\rho_{4} F Q_{i, t}+\vartheta_{i, t}
$$

\begin{tabular}{|c|c|c|c|c|c|c|c|c|}
\hline Variable & $\begin{array}{c}F Q 1 \\
(1)\end{array}$ & $\begin{array}{c}F Q^{2} \\
(2)\end{array}$ & $\begin{array}{c}F Q 3 \\
(\mathbf{3})\end{array}$ & $\begin{array}{c}F Q 4 \\
(4)\end{array}$ & $\begin{array}{c}I V 1 \\
(5)\end{array}$ & $\begin{array}{c}I V 2 \\
(6)\end{array}$ & $\begin{array}{c}I V 3 \\
(7)\end{array}$ & $\begin{array}{c}I \mathrm{V4} \\
(8)\end{array}$ \\
\hline BETA & $\begin{array}{l}0.018 \\
(1.18) \\
\end{array}$ & $\begin{array}{l}0.022 \\
(0.98) \\
\end{array}$ & $\begin{array}{l}0.020 \\
(1.04) \\
\end{array}$ & $\begin{array}{l}0.024 \\
(1.21) \\
\end{array}$ & $\begin{array}{l}0.012 \\
(1.06) \\
\end{array}$ & $\begin{array}{l}0.016 \\
(0.81) \\
\end{array}$ & $\begin{array}{l}0.012 \\
(0.92)\end{array}$ & $\begin{array}{l}0.018 \\
(1.06) \\
\end{array}$ \\
\hline SIZE & $\begin{array}{c}-0.0048 \\
(-4.58) \\
\end{array}$ & $\begin{array}{l}-0.051 \\
(-5.01) \\
\end{array}$ & $\begin{array}{l}-0.049 \\
(-4.57) \\
\end{array}$ & $\begin{array}{l}-0.038 \\
(-4.68) \\
\end{array}$ & $\begin{array}{c}-0.0042 \\
(-4.16) \\
\end{array}$ & $\begin{array}{l}-0.038 \\
(-4.25) \\
\end{array}$ & $\begin{array}{l}-0.041 \\
(-4.27) \\
\end{array}$ & $\begin{array}{l}-0.036 \\
(-4.12) \\
\end{array}$ \\
\hline$B \_M$ & $\begin{array}{c}0.0024 \\
(2.90)\end{array}$ & $\begin{array}{l}0.0021 \\
(3.12)\end{array}$ & $\begin{array}{l}0.0019 \\
(2.94)\end{array}$ & $\begin{array}{c}0.0018 \\
(2.68)\end{array}$ & $\begin{array}{c}0.0019 \\
(2.87)\end{array}$ & $\begin{array}{c}0.0020 \\
(3.07)\end{array}$ & $\begin{array}{l}0.0012 \\
(2.46)\end{array}$ & $\begin{array}{l}0.0016 \\
(2.70)\end{array}$ \\
\hline$F Q 1$ & $\begin{array}{l}0.024 \\
(3.97)\end{array}$ & & & & $\begin{array}{l}0.019 \\
(0.54)\end{array}$ & & & \\
\hline$F Q 2$ & & $\begin{array}{l}0.035 \\
(4.87)\end{array}$ & & & & $\begin{array}{l}0.024 \\
(0.81)\end{array}$ & & \\
\hline$F Q 3$ & & & $\begin{array}{l}0.039 \\
(4.62)\end{array}$ & & & & $\begin{array}{l}0.021 \\
(0.78)\end{array}$ & \\
\hline$F Q 4$ & & & & $\begin{array}{l}0.021 \\
(3.87)\end{array}$ & & & & $\begin{array}{l}0.014 \\
(0.66)\end{array}$ \\
\hline $\begin{array}{l}\text { Mean Adj. } \\
\boldsymbol{R}^{2}\end{array}$ & 0.08 & 0.07 & 0.08 & 0.09 & 0.09 & 0.08 & 0.08 & 0.09 \\
\hline
\end{tabular}

T-statistics are reported in parentheses.

Table 4 reports mean coefficients and corresponding t-statistics (corrected for serial-correlation) from yearly OLS regressions.

The dependent variable is $R_{F F}=$ expected return estimated using the Fama and French three-factor model; $F Q 1$ $=$ absolute value of residuals estimated using Barth et al. (2001) model; $F Q 2=$ standard deviation of residuals estimated using Barth et al. (2001) model calculated over years $t$-4 through $t ; F Q 3=$ absolute value of residuals estimated using a modified Dechow and Dichev (2002) model as implemented in Francis et al. (2004, 2005); FQ4 = standard deviation of residuals estimated using a modified Dechow and Dichev (2002) model as implemented in Francis et al. $(2004,2005)$ calculated over years $t$-4 through $t ; I V 1-I V 4$ are instrumental variables based on $F Q 1-F Q 4$ respectively.

The results from estimating equation (6) are reported in Table 4. Columns 1-4 report the results of estimating equation (6) using $F Q 1-F Q 4$, while columns 5-8 report the results using the instrumental variables. Consistent with the previously reported results, reporting quality does not appear to be an additional priced factor, once the firm-specific characteristics determining reporting quality have been accounted for. ${ }^{9}$

\footnotetext{
${ }^{9}$ The above evidence is consistent with the results in Core et al. (2007) that the accruals quality factor introduced in Francis et al. (2005) is not a significant priced risk factor. In particular, Core et al. (2007) question the specification of the asset-pricing tests implemented by Francis et al. (2005) and fail to find any evidence that accruals quality is indeed a priced risk factor that entitles a positive risk premium.
} 


\subsubsection{Reporting Quality and Total Risk}

Table 5 presents the results regarding the association between reporting quality and the standard deviation of stock returns. The results in Table 5 indicate that higher reporting quality, even after controlling for reporting quality determinants leads to significantly lower stock returns volatility.

\section{Table 5}

Standard Deviation of Stock Returns and Reporting Quality

$\operatorname{STDRET}_{i, t}=\chi_{0}+\chi_{1} \operatorname{SIZE}_{i, t}+\chi_{2} B_{-} M_{i, t}+\chi_{3} F Q_{i, t}+\xi_{i, t}$

\begin{tabular}{|c|c|c|c|c|c|c|c|c|}
\hline Variable & $\begin{array}{c}F Q 1 \\
(1)\end{array}$ & $\begin{array}{c}F Q 2 \\
(2)\end{array}$ & $\begin{array}{c}F Q 3 \\
(3)\end{array}$ & $\begin{array}{c}F Q 4 \\
(4)\end{array}$ & $\begin{array}{c}I V 1 \\
(5)\end{array}$ & $\begin{array}{c}I V 2 \\
(6)\end{array}$ & $\begin{array}{c}I V 3 \\
(7)\end{array}$ & $\begin{array}{c}I V 4 \\
(8)\end{array}$ \\
\hline SIZE & $\begin{array}{l}-0.0024 \\
(-7.95)\end{array}$ & $\begin{array}{l}-0.0031 \\
(-8.49)\end{array}$ & $\begin{array}{l}-0.0018 \\
(-7.41)\end{array}$ & $\begin{array}{l}-0.0021 \\
(-8.94)\end{array}$ & $\begin{array}{l}-0.0017 \\
(-7.41)\end{array}$ & $\begin{array}{l}-0.0024 \\
(-7.25)\end{array}$ & $\begin{array}{l}-0.0012 \\
(-6.57)\end{array}$ & $\begin{array}{l}-0.0015 \\
(-7.05)\end{array}$ \\
\hline B_M & $\begin{array}{c}-0.0041 \\
(-3.43)\end{array}$ & $\begin{array}{c}-0.0084 \\
(-2.99)\end{array}$ & $\begin{array}{c}-0.0054 \\
(-3.55)\end{array}$ & $\begin{array}{c}-0.0079 \\
(-3.14)\end{array}$ & $\begin{array}{l}-0.0031 \\
(-3.25)\end{array}$ & $\begin{array}{c}-0.0054 \\
(-2.45)\end{array}$ & $\begin{array}{c}-0.0024 \\
(-2.98)\end{array}$ & $\begin{array}{c}-0.0043 \\
(-2.76)\end{array}$ \\
\hline$F Q 1$ & $\begin{array}{l}0.018 \\
(4.17)\end{array}$ & & & & $\begin{array}{l}0.015 \\
(3.54)\end{array}$ & & & \\
\hline$F Q 2$ & & $\begin{array}{l}0.024 \\
(3.74)\end{array}$ & & & & $\begin{array}{l}0.019 \\
(3.28)\end{array}$ & & \\
\hline$F Q 3$ & & & $\begin{array}{l}0.015 \\
(3.15)\end{array}$ & & & & $\begin{array}{l}0.012 \\
(3.07)\end{array}$ & \\
\hline$F Q 4$ & & & & $\begin{array}{l}0.021 \\
(2.99)\end{array}$ & & & & $\begin{array}{l}0.016 \\
(2.92)\end{array}$ \\
\hline $\begin{array}{l}\text { Mean Adj. } \\
R^{2}\end{array}$ & 0.11 & 0.12 & 0.12 & 0.14 & 0.12 & 0.12 & 0.13 & 0.14 \\
\hline
\end{tabular}

T-statistics are reported in parentheses.

Table 5 reports mean coefficients and corresponding t-statistics (corrected for serial-correlation) from yearly OLS regressions.

The dependent variable is the standard deviation of daily holding period returns averaged over the 12 months starting as of June subsequent to fiscal year $t ; F Q 1=$ absolute value of residuals estimated using Barth et al. (2001) model; FQ2 = standard deviation of residuals estimated using Barth et al. (2001) model calculated over years $t$-4 through $t ; F Q 3=$ absolute value of residuals estimated using a modified Dechow and Dichev (2002) model as implemented in Francis et al. $(2004,2005)$; FQ4 = standard deviation of residuals estimated using a modified Dechow and Dichev (2002) model as implemented in Francis et al. (2004, 2005) calculated over years $t$-4 through $t ; I V 1-I V 4$ are instrumental variables based on $F Q 1-F Q 4$ respectively. 
Table 6

Idiosyncratic Risk and Reporting Quality

$\operatorname{IDIOS}_{i, t}=\lambda_{0}+\lambda_{1}$ SIZE $_{i, t}+\lambda_{2} B_{-} M_{i, t}+\lambda_{3} F Q_{i, t}+\pi_{i, t}$

\begin{tabular}{|c|c|c|c|c|c|c|c|c|}
\hline Variable & $F Q 1$ & $F Q 2$ & $F Q 3$ & $F Q 4$ & $I V 1$ & IV 2 & IV3 & IV4 \\
\hline SIZE & $\begin{array}{l}-0.0025 \\
(-12.81) \\
\end{array}$ & $\begin{array}{l}-0.0031 \\
(-11.69) \\
\end{array}$ & $\begin{array}{l}-0.0038 \\
(-14.51)\end{array}$ & $\begin{array}{l}-0.0041 \\
(-12.51) \\
\end{array}$ & $\begin{array}{c}-0.0017 \\
(-7.41)\end{array}$ & $\begin{array}{c}-0.0024 \\
(-7.25)\end{array}$ & $\begin{array}{c}-0.0012 \\
(-6.57)\end{array}$ & $\begin{array}{c}-0.0015 \\
(-7.05)\end{array}$ \\
\hline$B \_M$ & $\begin{array}{c}-0.0011 \\
(-7.31) \\
\end{array}$ & $\begin{array}{c}-0.0015 \\
(-5.68)\end{array}$ & $\begin{array}{c}-0.0012 \\
(-4.98) \\
\end{array}$ & $\begin{array}{c}-0.0014 \\
(-4.66) \\
\end{array}$ & $\begin{array}{l}-0.0031 \\
(-3.25)\end{array}$ & $\begin{array}{c}-0.0054 \\
(-2.45) \\
\end{array}$ & $\begin{array}{c}-0.0024 \\
(-2.98)\end{array}$ & $\begin{array}{c}-0.0043 \\
(-2.76)\end{array}$ \\
\hline$F Q 1$ & $\begin{array}{l}0.0355 \\
(11.59) \\
\end{array}$ & & & & $\begin{array}{l}0.015 \\
(3.54) \\
\end{array}$ & & & \\
\hline$F Q 2$ & & $\begin{array}{l}0.0447 \\
(10.89)\end{array}$ & & & & $\begin{array}{l}0.019 \\
(3.28)\end{array}$ & & \\
\hline$F Q 3$ & & & $\begin{array}{c}0.0551 \\
(9.98)\end{array}$ & & & & $\begin{array}{l}0.012 \\
(3.07)\end{array}$ & \\
\hline$F Q 4$ & & & & $\begin{array}{c}0.054 \\
(11.05) \\
\end{array}$ & & & & $\begin{array}{l}0.016 \\
(2.92)\end{array}$ \\
\hline $\begin{array}{l}\text { Mean } \\
\text { Adj. } R^{2}\end{array}$ & 0.34 & 0.35 & 0.36 & 0.36 & 0.12 & 0.12 & 0.13 & 0.14 \\
\hline
\end{tabular}

T-statistics are reported in parentheses.

Table 6 reports mean coefficients and corresponding t-statistics (corrected for serial-correlation) from yearly OLS regressions.

The dependent variable is the residual variance from a regression of firm-specific stock returns on the valueweighted CRSP stock index for 12 months following June subsequent to year $t ; F Q 1=$ absolute value of residuals estimated using Barth et al. (2001) model; $F Q 2=$ standard deviation of residuals estimated using Barth et al. (2001) model calculated over years $t$-4 through $t ; F Q 3=$ absolute value of residuals estimated using a modified Dechow and Dichev (2002) model as implemented in Francis et al. (2004, 2005); FQ4 = standard deviation of residuals estimated using a modified Dechow and Dichev (2002) model as implemented in Francis et al. $(2004,2005)$ calculated over years $t-4$ through $t ; I V 1-I V 4$ are instrumental variables based on $F Q 1-F Q 4$ respectively.

As discussed in section 3, the standard deviation of stock returns proxies for the firm's total risk. By examining the evidence in Table 6, one can distinguish between the effects of reporting quality on both the systematic and idiosyncratic risk components of stock return volatility. The results in Table 6 suggest that once the firm-specific characteristics determining the quality of financial reporting quality have been accounted for, information quality is significantly associated with idiosyncratic risk. This last set of results helps us reconcile the evidence regarding the overall pricing effects of financial reporting quality. To summarize, the reported results imply that reporting quality is significantly associated with the firm's total risk and the idiosyncratic component, but not with the equity cost of capital, the systematic component that translates into higher expected required risk premiums. Taken together, the evidence suggests that, although reporting quality may proxy for uncertainty or information risk, this type of firm-specific information risk does not seem to be systematically priced by investors, and it does not increase the firm's equity cost of capital. In other words, the firm-specific uncertainty regarding the estimation of future payoffs does not translate into a higher cost of equity capital. This evidence is consistent with the recent theoretical predictions advanced 
by Hughes et al. (2007) regarding the systematic and idiosyncratic pricing effects of information quality.

\section{Conclusion}

This paper provides empirical evidence on the determinants and consequences associated with the quality of financial reporting policies. The evidence suggests that the information risk arising from the quality of financial reporting does not affect the equity cost of capital once the endogenous nature of this information risk has been accounted for. These results indicate that reporting quality is not necessarily an additional systematic risk factor which investors price, but rather an idiosyncratic one. Although financial reporting quality is not significantly associated with the systematic components of asset returns, as proxied by the equity cost of capital, it is associated with firm-specific uncertainty and estimation precision. These findings are consistent with the theoretical predictions of Lambert et al. (2007) and Hughes et al. (2007) who argue that the information quality effect in the Easley and O'Hara (2004) model is a diversifiable phenomenon and should not affect risk premiums in large economies.

This study contributes to the extant accounting literature in several ways. First, the study contributes to the body of research analyzing the consequences of financial reporting quality policies. In particular, the findings illustrate the importance of explicitly modeling the specific factors determining financial reporting quality when investigating the associated economic consequences. Failing to do so may lead to spurious inferences, as indicated by the results. Secondly, this study's findings show the importance of accounting not only for the expected benefits associated with financial reporting policies, but also for the constraining factors and other firm-specific characteristics affecting financial reporting policies.

\section{References}

Barth, M., D.P. Cram and K. Nelson, 2001, “Accruals and the Prediction of Future Cash Flows", The Accounting Review 76, 27-58.

Botosan, C., 1997, "Disclosure Level and the Cost of Equity Capital", The Accounting Review 72, 323-349.

Claus, J. and J. Thomas, 2001, "Equity Premia as Low as Three Percent? Evidence from Analysts' Earnings Forecasts for Domestic and International Stock Markets", Journal of Finance 56, 1629-1666.

Core, J., W. Guay and R. Verdi, 2007, “Is Accruals Quality a Priced Risk Factor?", Journal of Accounting and Economics, Forthcoming.

Darrough, M. and N. Stoughton, 1990, "Financial Disclosure Policy in an Entry Game", Journal of Accounting and Economics 12, 219-243.

Dechow, P. and I. Dichev, 2002, "The Quality of Accruals and Earnings: The Role of Accrual Estimation Errors", The Accounting Review 77 (Supplement), 35-59. 
Diamond, D. and R. Verrecchia, 1991, "Disclosure, Liquidity, and the Cost of Capital", The Journal of Finance 66, 1325-1355.

Dye, R.A., 1985, "Disclosure of Nonproprietary Information", Journal of Accounting Research 23, 123-145.

Easley, D. and M. O'Hara, 2004, "Information and the Cost of Capital", The Journal of Finance 59, 1553-1583.

Easley, D., S. Hvidkjaer, and M. O'Hara. 2002. "Is Information Risk a Determinant of Assets Returns?" Journal of Finance 57: 2185-2221

Easton, P., 2004, "PE Ratios, PEG Ratios, and Estimating the Implied Expected Rate of Return on Equity Capital", The Accounting Review 79, 73-95.

Fama, E.F. and K. French, 1993, "Common Risk Factors in the Returns on Stocks and Bonds", Journal of Financial Economics 33, 3-56.

Fields T.D., T.Z. Lys and L. Vincent, 2001, "Empirical Research on Accounting Choice”, Journal of Accounting and Economics 31, 255-307.

Francis, J., R. LaFond, P. Olsson and K. Schipper, 2005, "The Market Pricing of Accruals Quality", Journal of Accounting and Economics 39, 295-327.

Francis, J., R. LaFond, P. Olsson and K. Schipper, 2004, "Cost of Capital and Earnings Attributes", The Accounting Review 79, 967-1010.

Gebhardt, W., C. Lee and B. Swaminathan, 2001, "Toward an Implied Cost of Capital", Journal of Accounting Research 39, 135-176.

Gode, D. and P. Mohanram, 2003, "Inferring the Cost of Capital Using the OhlsonJuettner Model", Review of Accounting Studies 8, 399-431.

Harris, M.S., 1998, “The Association between Competition and Managers' Business Segment Reporting Decisions", Journal of Accounting Research 36, 111-128.

Healy, P.M. and K.G. Palepu, 2001, "Information Asymmetry, Corporate Disclosure, and the Capital Markets: A Review of the Empirical Disclosure Literature", Journal of Accounting and Economics 31, 405-440.

Hughes, J., J. Liu and J. Liu, 2007, "Information Asymmetry, Diversification, and Cost of Capital", The Accounting Review 82(3), 705-730.

Jensen, M. and W.H. Meckling, 1976, "The Theory of the Firm: Managerial Behavior, Agency Costs and Ownership Structure", Journal of Financial Economics 3, 305360 .

Kasznik, R. and B. Lev, 1995, "To Warn or Not to Warn: Management Disclosures in the Face of Earnings Surprises", The Accounting Review 70, 113-134.

Lambert, R., C. Leuz and R. Verrecchia, 2007, “Accounting Information, Disclosure, and the Cost of Capital", Journal of Accounting Research 45, 385-419.

Lang, M. and R. Lundholm, 1996, "Corporate Disclosure Policy and Analyst Behavior",The Accounting Review 71, 467-492.

Lang, M. and R. Lundholm, 1993, "Cross-sectional Determinants of Analyst Ratings of Corporate Disclosures", Journal of Accounting Research 31, 246-271.

Leuz, C. and R. Verrecchia, 2000, “The Economic Consequences of Increased Disclosure”, Journal of Accounting Research 38 (Supplement), 91-124.

Maddala, G.S., 1983, Limited-Dependent and Qualitative Variables in Econometrics (New York, NY: Cambridge University Press). 
Ohlson, J.A. and B.E. Juettner-Nauroth, 2005, "Expected EPS and EPS Growth as Determinants of Value", Review of Accounting Studies 10, 349-366.

Verrecchia, R.E., 1990, "Endogenous Proprietary Costs through Firm Interdependence", Journal of Accounting and Economics 12, 245-251.

Wooldridge, J.M., 2002, Econometric Analysis of Cross Section and Panel Data, (Cambridge, Massachusetts: The MIT Press). 